\title{
Autonomia świata a podmiotowość człowieka w ekoteologii
}

We współczesnych dyskusjach na temat kryzysu ekologicznego odpowiedzialnością za zniszczenie środowiska przyrodniczego obarczana jest przede wszystkim kultura europejska $z$ jej antropocentryzmem i instrumentalnym podejściem do rzeczywistości materialnej ${ }^{1}$. Z kolei źródeł takiego ukształtowania kultury Zachodu doszukuje się w jej chrześcijańskich i biblijnych fundamentach, które - w opinii wielu środowisk - konstytuują panowanie człowieka nad przyrodą i uprawomocniają jej niszczenie ${ }^{2}$. Szansą na przezwyciężenie mentalności instrumentalnego podejścia do rzeczywistości pozaludzkiej mają być biocentryczne koncepcje ekofilozoficzne, w których przyrodzie przypisywana jest wartość immanentna i prawo do realizacji wpisanych w nią celów naturalnych ${ }^{3}$. W płasz-

Por. A. Ganowicz-Bączyк, Spór o etykę środowiskowa, Kraków 2009, s. 11-46; J. SeED, Antropocentryzm, w: B. Devall, G. Sessions, Ekologia głęboka, Warszawa 1995, s. 316-320; A. PAPUZIŃsKi, Metafizyczne dziedzictwo nauki jako problem filozofi ekologii, w: W. Tyburski (red.), Ekofilozofia i bioetyka. Materiały VI Polskiego Zjazdu Filozoficznego w Toruniu, Toruń 1996, s. 29-41; W. TYвURSKi, Etyka środowiskowa a paradygmat antropocentryzmu, w: tenże (red.), Ekofilozofia, s. 68; tenże, System wartości i etyczna ochrona środowiska przyrodniczego, w: tenże (red.), Człowiek i środowisko. Dyscypliny humanistyczne i ekologia, Toruń 1995, s. 72-75.

2 Zarzut antropocentryzmu chrześcijaństwa, a szczególnie katolicyzmu, podnoszony jest zwłaszcza przez przedstawicieli koncepcji biocentrycznych, którzy odpowiedzialnością za kryzys ekologiczny obarczają mentalność budowaną na fundamencie biblijnego „panowania” człowieka nad światem (por. Rdz 1, 28). Jako pierwszy tezę taką postawił Lynn White. Por. L. White, The historical roots of our ecoligic crisis, „Science” 155 (1967), s. 1203-1207; zob. także H. Skolimowski, Nowe oblicze Boga w dobie ekologicznej, w: J. Dębowski (red.), Religia a ruchy ekofilozoficzne, Olsztyn 1996, s. 17-20. Por. W. KNoch, Świat - dobre stworzenie Boga?, „Communio” 12 (1992), nr 6, s. 5; J. Grzesica, Ochrona środowiska naturalnego człowieka, Katowice 1993, s. 61-63. Obecnie zauważa się wprawdzie, że jest to mocno uproszczone podejście, w którym nie uwzględniono negatywnego wpływu oświeceniowej mentalności, wyemancypowanej z odniesień do Boga, na sposób interpretacji Biblii, jednak nie przeszkadza to w uznaniu biblijnych wersetów za stanowiące zagrożenie dla kształtowania świadomości proekologicznej. Por. A. PAPUZIŃsKI, Kryzys ekologiczny a chrześcijańska doktryna religijna, w: J. Dębowski (red.), Religia, s. 54-63; I. Czaczkowska, Pomiędzy potopem a tęcza. Ekumeniczne studium integralności stworzenia, Lublin 1998, s. 34-45.

3 Por. М. Вомвік, Podstawy i metodologia tzw. ekologii głębokiej, „Studia Ecologiae et Bioethicae” 3 (2005), s. 381-382; A. GANOwiCz-BĄCZYK, dz. cyt., s. 55-98; A. NAEss, Musimy stuchać swoich 
czyźnie etyki wyrażają się one w argumentacji teleologicznej za ochroną przyrody: skoro ma ona strukturę teleologiczną to posiada także prawo do realizacji jej immanentnych celów. Implikacją takiego stanowiska jest odebranie człowiekowi prawa do wykorzystywania rzeczywistości przyrodniczej, wykraczającego poza zaspokajanie podstawowych potrzeb życiowych. Jego obowiązkiem jest afirmacja wszystkiego, co żyje, uszanowanie i ochrona odkrywanych w przyrodzie celów ${ }^{4}$. Mimo częstego utożsamiania chrześcijańskiej koncepcji odniesień człowieka do świata materialnego - stanowiska teocentrycznego, nazywanego ekoteologią - ze stanowiskiem antropocentrycznym ${ }^{5}$, w nauczaniu Kościoła odnaleźć można wypowiedzi, świadczące o zakwestionowaniu niektórych założeń antropocentryzmu ${ }^{6}$, podobnie jak i stwierdzenia kwestionujące tezy biocentryzmu. Czym charakteryzuje się zatem wynikająca $\mathrm{z}$ chrześcijaństwa koncepcja odniesień człowieka do przyrody? Jak rozumie ona świat pozaludzki i jego wewnętrzną celowość? Dlaczego kwestionuje antropocentryzm? Jak ujmuje podmiotowość człowieka w odniesieniu do przyrody? Jakie wysuwa propozycje w zakresie budowania takich odniesień człowieka do przyrody, które pozwolą przezwyciężyć kryzys ekologiczny?

uczuć, w: A. J. Korbel (red.), O przyrodzie i człowieku. Rozmowy Dzikiego Życia, Bielsko-Biała 2001, s. 12; Z. WRóBLEWSKI, Uwagi na temat kontrowersji antropocentryzm - biocentryzm w etyce ekologicznej, w: J. W. CZARToszewsKi (red.), Etyka środowiskowa wyzwaniem XXI wieku, Warszawa 2002, s. 73, 76.

4 Por. Z. WróBlewski, Natura - cele naturalne - wartości i normy. Analiza argumentu teleologicznego w ujęciu praktycznej filozofii przyrody, „Studia Philosophiae Christianae” 45 (2009), nr 1, s. 202-204.

5 Por. J. Grześkowiak, Teologiczne przesłanki odpowiedzialności za środowisko przyrodnicze, „Roczniki Teologiczno-Kanoniczne” 27 (1980), nr 6, s. 10-11; H. LANGKammer, Biblia a ekologia, „Zeszyty Naukowe KUL” 36 (1993), nr 1-4, s. 4-5.

6 Wiele z pojawiających się we współczesnych dyskusjach problemów ma swoje źródło w niejednoznacznej terminologii. Wprowadzenie najbardziej ogólnego dzielenia stanowisk na antropocentryczne i biocentryczne sprawia, że chrześcijaństwo faktycznie bliższe jest antropocentryzmowi niż biocentryzmowi. Tymczasem w ramach antropocentryzmu wyróżnia się zarówno antropocentryzm słaby, jak i antropocentryzm mocny. Proponuje się ponadto odróżnienie antropocentryzmu od homocentryzmu, który pozwala na nieliczenie się $\mathrm{w}$ działaniach $\mathrm{z}$ dobrem przyrody. Por. A. Ganowicz-BĄCzyK, dz. cyt., s. 12-27. Zbytnim uproszczeniem jest również sprowadzanie całej myśli chrześcijańskiej w tej kwestii do jednego ujęcia. W jej ramach funkcjonują bowiem zarówno koncepcje antropocentryczne, wychodzące w rozważaniach od godności człowieka jako kryterium dobra i zła moralnego (Zob. np. T. ŚLIPKO, Ekologiczna doktryna Kościoła, w: T. ŚlıPкo, A. Zwoliński, Rozdroża ekologii, Kraków 1999; W. Bołoz, Etyczne uwarunkowanie edukacji ekologicznej rodziny, w: tenże (red.), Edukacja ekologiczna rodziny. Stan, możliwości, programy, Warszawa 1995, s. 23-26; M. Wyrostкiewicz, Ekologia ludzka. Osoba i jej środowisko z perspektywy teologicznomoralnej, Lublin 2007), jak i stanowiska teocentryczne, kreślące najpierw perspektywę relacji między Stwórcą i stworzeniem jako fundament dla rozważań o relacji między człowiekiem i przyrodą. Celem niniejszego tekstu jest naszkicowanie koncepcji teocentrycznej. 


\section{Autonomia świata w ekoteologii}

Dokonującemu się na przestrzeni wieków rozwojowi człowieka towarzyszyło przekonanie, że może on jedynie odkrywać i w niewielkim stopniu wykorzystywać prawa rządzące przyrodą. Jego wiedza była na tyle ograniczona, że oparte na niej działania miały na celu przede wszystkim zaspokajanie własnych potrzeb egzystencjalnych. Dopiero XX wiek przyniósł świadomość, że cywilizacja ludzka posiada znaczący wpływ na kształt planety, którą zamieszkuje. Z tego też względu dopiero $\mathrm{w}$ XX wieku zrodziło się pytanie o granice ingerencji w przyrodę i stwierdzenie konieczności uszanowania wewnętrznej celowości bytów pozaludzkich. W nauczaniu Kościoła zostało ono w sposób wyraźny wypowiedziane w Konstytucji duszpasterskiej o Kościele w świecie współczesnym Gaudium et spes: „rzeczy stworzone (...) cieszą się własnymi prawami i wartościami (...). Ze względu bowiem na sam fakt stworzenia wszystkie rzeczy uzyskują właściwą im trwałość, prawdziwość, dobro, a także własne prawa i porządek, które człowiek powinien szanować" ( $\mathrm{nr} 36)^{7}$.

Głębsze przyjrzenie się niniejszej problematyce wskazuje jednak, że powyższe stwierdzenie może być co najwyżej uznane za wyraźne sformułowanie tego, co zawiera biblijne objawienie. Wniosek taki wynika chociażby z analizy opowiadania o stworzeniu świata i człowieka. Nie tylko dzieło, jakim jest człowiek, zostało ocenione jako dobre, ale również inne stworzenia zostały ocenione $\mathrm{w}$ ten sam sposób (por. Rdz 1, 1-2, 4). W jakim sensie należy jednak rozumieć ową «dobroć»? Czy «dobroć» zwierząt i roślin związana jest z faktem ich użyteczności dla człowieka? Lektura Biblii skłania do negatywnej weryfikacji tej tezy. W Mądrości Syracha znajdują się wersety mówiące o tym, że poprzez stworzenie Bóg objawia swoją chwałę: „chwała Pana napełnia jego dzieło” $(42,16)$, które następnie zostaje rozwinięte w odniesieniu do słońca („Widok wschodzącego słońca mówi [nam], / że jest ono czymś najbardziej godnym podziwu, dziełem Najwyższego” - 43, 2), księżyca, gwiazd i tęczy („Patrz na tęczę i wychwalaj Tego, który ją uczynił, / nadzwyczaj piękna jest w swoim blasku: / otacza niebo kręgiem wspaniałym, / a napięły ją ręce Najwyższego" - 43, 11-12). Podobne przesłanie zawierają psalmy (por. np. Ps 8, 2. 4-5. 10) oraz inne biblijne księgi ${ }^{8}$. W Księdze

Cytowany fragment pochodzi z rozdziału, poświęconego aktywności ludzkiej w świecie, a ściśle rzecz ujmując autonomii ziemskiej aktywności człowieka, oddaje jednak chrześcijańskie podejście do świata przyrody.

8 Por. M. Ostrowski, Ekologia w oczach turysty i pielgrzyma, w: A. Dyduch-Falniowska, M. Grzegorczyk, J. Perzanowska, Z. J. Kijas, Z. Mirek (red.), Mówić o przyrodzie. Zintegrowana wizja przyrody, Kraków 2001, s. 53-66; W. KNoch, dz. cyt., s. 15; W. BoŁoz, Biblijne podstawy ekoteologii, w: J. M. DoŁęGa, J. W. Czartoszewski, A. Skowroński (red.), Ochrona środowiska społeczno-przyrodniczego w filozofii i teologii, Warszawa 2001, s. 345-346; S. Urbański, Mistyka ekologicznej duchowości świata, w: J. M. DoŁĘGA, J. W. Czartoszewski, A. Skowroński (red.), dz. cyt., s. 309-312; R. Kempiak, Stworzenie jako obraz Boga w Biblii, w: 
Mądrości odnaleźć można z kolei słowa, wskazujące na miłość Boga do swojego dzieła: „Miłujesz bowiem wszystkie stworzenia, / niczym się nie brzydzisz, co uczyniłeś (...). Oszczędzasz wszystko, bo to wszystko Twoje, Panie, miłośniku życia" $(11,24.26)^{9}$. Nie brak również fragmentów, świadczących o zatroskaniu Boga losami przyrody: „On daje pokarm bydłu, / pisklętom kruka to, o co wołają" (Ps 147, 9; por. Ps 145, 15-16). Według Biblii, natura pozostaje zatem w relacji do Boga niezależnej od tej relacji, jaką buduje człowiek. Każda istota żywa jest we właściwy sobie sposób partnerem Boga ${ }^{10}$. Interpretując te fragmenty, można uznać, że sam akt stworzenia oznacza zbudowanie relacji ze Stwórcą, a w konsekwencji także posiadanie wewnętrznej wartości, godności (por. KKK 339). Owa godność wspólna jest ludziom, zwierzętom i całej rzeczywistości materialnej ${ }^{11}$.

O autonomicznej relacji między Stwórcą i stworzeniem świadczą również specyficzne fragmenty w Biblii, mówiące o modlitwie stworzeń. Bardzo często nie zwraca się na nie uwagi ${ }^{12}$, tymczasem na przykład w Księdze Psalmów pojawia się stwierdzenie: „Niech rzeki klaszczą w dłonie, / niech góry razem wołają radośnie / przed obliczem Pana, który nadchodzi” (98, 8-9a). Także inne psalmy zawierają wersety wskazujące, że ziemia swym istnieniem i bogactwem składa Bogu chwałę (por. Ps 19; 96; 104) ${ }^{13}$. Z kolei w Księdze Daniela znajduje się hymn uwielbienia Stwórcy, wypowiadany przez poszczególne dzieła Boga, rozpoczynając od ciał niebieskich, poprzez góry, rzeki, morza, rośliny, a na zwierzętach i człowieku kończąc (por. 3, 51-90). Prawdę o uwielbieniu Boga przez jego dzieła podkreśla również Katechizm Kościoła Katolickiego, gdy podejmuje problema-

S. Niziński (red.), Ekologia a duchowość chrześcijańska, Poznań 2009, s. 7-20. Na temat stworzenia jako znaku obecności Boga - obecności, która nie jest tożsamością ze stworzonym światem, zobacz: R. Rogowski, Teoekologia. Mistyka wszystkich rzeczy, Kraków 2002. R. Rogowski wyjaśnia między innymi różnicę między panteizmem, charakterystycznym dla współczesnych nurtów biocentrycznych, a panenteizmem, który przyjmowany jest na gruncie chrześcijańskim. Por. tamże, s. 40-42.

9 Por. J. Suchy, Czyńcie sobie ziemię poddaną, panujcie nad zwierzętami, „Zeszyty Naukowe KUL” 36 (1993), nr 1-4, s. 20-21; W. Bołoz, Biblijne, s. 352-353.

10 Por. C. Naumowicz, Eko-teologia jako forma chrześcijańskiej diakonii wobec stworzenia, „Studia Ecologiae et Bioethicae" 7 (2009), nr 1, s. 229; S. ZIĘBA, Religia a ekologia, w: tenże (red.), Konferencje ekologiczne, Lublin 1995, s. 18; P. KęDZIERSKI, Kościót i ekologia, Rzeszów 1997, s. 50.

11 Por. J. Łuкомsкi, Solidarność człowieka z przyroda, Radom 1994, s. 25; J. Grzesica, dz. cyt., s. 72; J. Dęвоwski, Ekologia osoby ludzkiej w chrześcijańskim nauczaniu społecznym, Olsztyn 2001, s. 13-15; W. Bo£oz, Biblijne, s. 347-349, 355; K. WojciechowsкI, Ekologia w nauczaniu Kościoła - przyroda jako dzieło Boga, w: S. Niziński (red.), dz. cyt., s. 42-43.

12 Por. J. SAliJ, Gwiazdy, ludzie i zwierzęta. O godności człowieka i godności materii, Kraków 2009, s. 128.

13 Por. S. ZiębA, dz. cyt., s. 16; J. Synowiec, Wprowadzenie do Księgi Psalmów, Kraków 1996, s. 271-272; R. Rubinkiewicz, Prorocza wizja odnowionego świata, „Zeszyty Naukowe KUL” 36 (1993), nr 1-4, s. 36-37; R. Rogowski, dz. cyt., s. 113-116, 133-146; P. KęDZIERsKi, dz. cyt., s. 54; L. Chenevière, Rozmowy o milczeniu, Kraków 2009, s. 144-147. 
tykę odniesienia człowieka do zwierząt. Według Katechizmu, zwierzęta samym swym istnieniem błogosławią Boga i oddają mu chwałę (por. KKK 2416). Myśl tę powtórzył Jan Paweł II w orędziu na Światowy Dzień Pokoju 1990, zatytułowanym Pokój z Bogiem Stwórca, pokój z całym stworzeniem: „Szacunek dla życia i dla ludzkiej godności zakłada także poszanowanie dla stworzenia i troskę o nie, gdyż jest ono wezwane, by wspólnie z człowiekiem chwalić Boga" (nr 16) ${ }^{14}$.

Mówiąc o celach, wpisanych w naturę poszczególnych stworzeń, jakie odczytuje się na płaszczyźnie teologii, nie sposób pominąć kwestii eschatologicznych. Teologia przyznaje, że rzeczywistość materialna posiada wpisane w siebie prawa (o uszanowanie których dopominają się kierunki biocentryczne), natomiast uznaje również, że ostatecznym celem wszechświata jest jego eschatologiczna doskonałość, nazywana «nowym niebem» i «nową ziemią» (Ap 21, 1; 2 P 3, 13; Rz 8, 19-22; por. KK 48; KKK 1043-1044) ${ }^{15}$. Jak mówi Jacek Salij, w czasach ostatecznych „nie tylko dopełni się (...) ostatecznie i na zawsze przebóstwienie całej ludzkości, ale nastąpi również jakieś tajemnicze odnowienie materialnego wszechświata, który stanie się «nowym niebem i nową ziemią»"16. Czesław Bartnik wyjaśnia z kolei, że nowy świat będzie ukształtowany w jakiejś ciągłości ze „starym, w oparciu o niego, nie jako stworzony z nicości, lecz jako jego przekształcenie, dostosowujące go do nowego rodzaju egzystencji człowieka - świat to rzeczywistość «stworzona», a następnie «odkupiona», «zbawiona», przy czym odkupienie i zbawienie łączą się ze sobą dialektycznie"17.

O ile więc Biblię trudno uznać za podręcznik ekologii czy kosmologii, to niewątpliwie ukazuje ona świat w planach Boga, od jego zaistnienia czasowego do ostatecznego przeznaczenia, a tym samym wskazuje na jego sens, logikę i wartość ${ }^{18}$. Oceniając chrześcijańskie stanowisko w określaniu wartości przyrody, należy więc przyznać, że jest ono również stanowiskiem nieantropocentrycznym. Różni się ono jednak od innych współczesnych ujęć nieantropocentrycznych wyraźnym związaniem wartości przyrody z jej relacją ze Stwórcą ${ }^{19}$.

\section{Podmiotowość człowieka w ekoteologii}

Stwierdzenie, że każde ze stworzeń jest we właściwy dla siebie sposób partnerem Boga, domaga się dopowiedzenia, że partnerstwo między Bogiem i człowiekiem ma inny charakter niż partnerstwo między Bogiem a bytami pozaludzkimi.

14 Odtąd SDzP1990 z odpowiednim numerem. Orędzie w: „L’Osservatore Romano” 10 (1989), nr 12 (119), s. 21-22.

15 Por. W. KNoch, dz. cyt., s. 10; P. KęDZierski, dz. cyt., s. 74-75.

16 J. SaliJ, dz. cyt., s. 77.

17 Cz. S. Bartnik, Dogmatyka katolicka, t. 2, Lublin 2003, s. 922-923.

18 Por. S. Zı̨̨BA, dz. cyt., s. 15.

19 Por. Cz. S. Bartnik, Dogmatyka katolicka, t. 1, Lublin 1999, s. 24-25. 
Człowiek - ze względu na swą rozumność i wolność - jest bowiem w nawiązywanych przez siebie relacjach podmiotem. Jego działania - w przeciwieństwie do aktywności zwierząt - albo budują relację z Bogiem, albo prowadzą do jej zerwania. Owe działania są zatem wyrazem dialogu z Bogiem. Biblia określa podstawowy cel ludzkiej egzystencji, jakim jest wieczne przebywanie z Bogiem, ale wskazuje równocześnie, że jego realizacja jest dla człowieka wyzwaniem, które może zostać podjęte albo odrzucone. W jaki sposób człowiek realizuje wpisane w naturę każdego Bożego dzieła eschatologiczne powołanie?

Odpowiedź na powyższe pytanie zawarta została już w zapisanym w Księdze Rodzaju opisie stworzenia świata i człowieka. Ujęte w biblijnych dziejach początku świata i ludzkości odnoszące się do człowieka słowa „niech panuje nad rybami morskimi, nad ptactwem powietrznym, nad bydłem, nad ziemią i nad wszystkimi zwierzętami pełzającymi po ziemi” ( $\mathrm{Rdz} 1,26)$ są bowiem umieszczone w kontekście słów o podobieństwie człowieka do Boga (por. Rdz 1, 26-27). Ono z kolei - ze względu na rozumność i wolność człowieka - nie może być odczytywane jedynie jako stwierdzenie faktu, ale powinno być interpretowane jako wezwanie, czyli z uwzględnieniem specyfiki ludzkiego bytu. Człowiek poprzez odniesienia do rzeczywistości, która go otacza, może albo upodabniać się do Boga, albo być mniej podobnym do Boga ${ }^{20}$. Słuszność dynamicznego rozumienia «podobieństwa» i jego powiązania z odniesieniami do przyrody potwierdza ponadto drugi opis stworzenia człowieka, który w momencie pojawienia się na świecie został powołany do «uprawiania i doglądania» ogrodu Eden (por. Rdz 2, 15) ${ }^{21}$.

Budowanie relacji z Bogiem i upodabnianie się do Stwórcy w swych działaniach albo zerwanie dialogu z Bogiem poprzez działania sprzeczne $z$ intencjami Stwórcy, odczytywanymi z jego dzieła, stanowi w teologii podstawowe kryterium moralności. Z opowiadania o stworzeniu, w którym «panowanie» łączy się z «upodabnianiem», wynika, że relacja ze stworzeniami jest dla człowieka przestrzenią o charakterze moralnym. Istnieje zatem zależność pomiędzy relacją z Bogiem a relacją ze stworzeniami. Pierwsze rozdziały Księgi Rodzaju wyrażają ponadto przekonanie, że nie tylko negatywne odniesienia do świata powodują zerwanie relacji z Bogiem, ale także zerwanie relacji z Bogiem zakłóca harmonię między człowiekiem i przyrodą. Prawidłowość ta uwidacznia się szczególnie mocno w sytuacji grzechu. Przesłanie Księgi Rodzaju jest wyraźne - zerwanie jedności z Bogiem skutkuje równocześnie rozdźwiękiem między ludźmi, co obrazują wzajemne oskarżenia, wypowiadane przez mężczyznę i kobietę, oraz dysharmonią między człowiekiem i przyrodą. Świadomość biblijnego autora co do

20 Por. J. Grześ́́nowiak, dz. cyt., s. 12-13; P. Kędzierski, dz. cyt., s. 54-57.

21 Por. J. BAgrowicz, „Czyńcie sobie ziemię poddana...” (Rdz 1,28), czyli jak dogladać i uprawiać ogród Eden, w: B. Przy borowska (red.), Natura, edukacja, kultura. Pedagogia źródeł, Toruń 2006, s. 97-100; J. Dęвоwski, Ekologia, s. 16-17; J. Łukomski, Próba zbudowania chrześcijańskiej etyki środowiska naturalnego, Kielce 2000, s. 341-345. 
tej ostatniej prawidłowości można odczytać z wersetu: „cierń i oset będzie ci ona [ziemia - przyp. J.H.] rodziła, a przecież pokarmem twym są płody roli” $(3,18)$. Ów rozdźwięk obejmuje nie tylko ziemię, ale także stworzenia ją zamieszkujące, czyli Biblia wyraźnie łączy negatywne odniesienia do świata przyrodniczego z ludzkim grzechem - tam, gdzie zerwana jest relacja z Bogiem, tam człowiek pozostaje $\mathrm{w}$ konflikcie z przyrodą, tam, gdzie człowiek buduje relację z Bogiem, tam w jego relacjach z przyrodą panuje harmonia ${ }^{22}$.

Zaprezentowane powyżej rozważania szkicują trójelementową relację, tworzoną przez Boga, człowieka i świat materialny. Jest to schemat prosty w komunikowaniu, nie do końca jednak uwzględniający wszystkie przesłanki, jakie płyną z Biblii dla naszkicowania związków między tymi trzema elementami. Zauważyć należy, że w opowiadaniach biblijnych sytuacja moralna człowieka ma swoją kontynuację w sytuacji świata. Grzech człowieka sprawia na przykład, że „ziemia staje się pełna wykroczeń” przeciw Bogu, „została skażona” (Rdz 6, 11.13) ${ }^{23}$ i dlatego Boże postanowienie zagłady obejmuje nie tylko człowieka, ale także „bydło, zwierzęta pełzające i ptaki powietrzne" (Rdz 6, 7; por. SDzP1990 3). Przytoczone wersety skłaniają do pytania, dlaczego świat posiadający autonomiczną relację z Bogiem miałby ponosić konsekwencje ludzkiego czynu? Dlaczego cierpi nie tylko na skutek postawy człowieka względem przyrody, ale jeszcze sam zostaje uznany za «skażony» i z tego względu przeznaczony do zagłady?

Zależność między kondycją świata i kondycją moralną człowieka ukazywana jest w Biblii nie tylko w przypadku grzechu, ale także w przypadku odnowy ziemskiej rzeczywistości (por. SDzP1990 4). Zawarta w ostatnich rozdziałach Księgi Izajasza apokalipsa wiąże zapowiadane już w Starym Testamencie «nowe niebo» i «nową ziemię» (Iz 65, 17; 66, 22) z odnową moralną człowieka. Podobnie nowotestamentalne wizje doskonałej rzeczywistości eschatologicznej uwzględniają zawsze odnowionego człowieka ${ }^{24}$. Najbardziej sugestywny jest pod tym względem starotestamentalny obraz z Księgi Izajasza: „Wtedy wilk zamieszka wraz z barankiem, / pantera z koźlęciem razem leżeć będą, / cielę i lew paść się będą społem / i mały chłopiec będzie je poganiał. / Krowa i niedźwiedzica przestawać będą przyjaźnie, / młode ich razem będą legały. / Lew też jak wół będzie jadał słomę. / Niemowlę igrać będzie na norze kobry, / dziecko włoży swą rękę do kryjówki żmii” (Iz 11, 6-8) ${ }^{25}$. Nawet jeżeli zrezygnuje się

22 Por. P. Lamarche, Zwierzęta, w: X. Léon-Dufour (red.), Słownik Teologii Biblijnej, Poznań 1990, s. 1149-1150; R. Rubinkiewicz, dz. cyt., s. 39; J. Dęвowski, Ekologia, s. 19-20; W. NowaCKi, Człowiek i świat w świetle odkupienia w nauczaniu Jana Pawła II, w: J. M. DoŁ̨̨GA, J. W. CzARToszewski, A. Skowroński (red.), dz. cyt., s. 361; P. Kędzierski, dz. cyt., s. 58-59, 62-63.

23 Por. J. Bagrowicz, dz. cyt., s. 101; W. Bo£oz, Biblijne, s. 348-349.

24 Por. K. Romaniuk, Perspektywy „kosmiczne” w soteriologii św. Pawła, „Roczniki Teologiczno-Kanoniczne" 13 (1966), s. 84-85; R. Rogowski, dz. cyt., s. 356; J. Dęвowski, Ekologia, s. 21-22; W. NOWACKI, dz. cyt., s. 361-363.

25 P. Lamarche, dz. cyt., s. 1150; K. Wojciechowski, dz. cyt., s. 43; R. Rubinkiewicz, dz. cyt., 
z literalnej interpretacji Biblii, jej przesłanie jest oczywiste - sytuacja świata zależy od kondycji moralnej człowieka (por. SDzP1990 5). Może zatem należałoby zastąpić trójelementowy schemat relacji między Bogiem, człowiekiem i światem schematem dwuelementowym, w którym pierwszym $\mathrm{z}$ „elementów” jest Bóg, a drugim Jego dzieło?

Jan Grzesica wskazuje, że we współczesnej teologii pojawiają się takie koncepcje. Odrzucając ekskluzjonizm, podkreślający jedynie transcendencję człowieka względem przyrody i nadający mu nad nią absolutną władzę, kwestionują one jednak również inkluzjonizm, włączający człowieka w definicję przyrody (co jest charakterystyczne dla biocentryzmu). Ujmując całościowo przyrodę i człowieka, włączają przyrodę w definicję człowieka, traktując ją jako «poszerzoną cielesność» człowieka ${ }^{26}$.

Nie próbując rozwiązywać dylematu, za pomocą jakiego schematu należy opisywać relację między Bogiem, człowiekiem i światem, można jednak wskazać, jakie prawdy implikują poszczególne ujęcia. Schemat dwuelementowy podkreśla zależność między losami człowieka i losami świata. Pozwala też interpretować człowieka jako istotę, dzięki której dzieło Boga nabiera nowej jakości - przestaje być zdeterminowane w swoim dążeniu do Boga, a staje się uczestnikiem dialogu, jaki toczy się między Stwórcą i stworzeniem, a ten - jak wiadomo - wymaga zaangażowania obu stron ${ }^{27}$. W schemacie dwuelementowym holistyczne podejście do rzeczywistości materialnej kłóci się jednak z doświadczeniem człowieka, który postrzega siebie jako odrębny byt. Zaletą schematu trójelementowego jest wskazywanie na indywidualne istnienie każdego $\mathrm{z}$ bytów, a w konsekwencji zbudowanie przestrzeni wzajemnych odniesień wewnątrz stworzonego świata, które ze względu na rozumność i wolność człowieka nabierają wymiaru moralnego. Wadą tego schematu jest jednak izolowanie świata materialnego od człowieka i otworzenie drogi do instrumentalnego wykorzystywania przyrody, co w praktyce może prowadzić do konsumpcjonizmu. Wydaje się więc, że obydwa schematy są niedoskonałe, choć obydwa pomagają zrozumieć relację między Bogiem, człowiekiem i przyrodą. Wykorzystując je, należy jednak pamiętać o ich ograniczeniach i traktować komplementarnie. $Z$ jednej bowiem strony człowiek jest odrębnym bytem, a $\mathrm{z}$ drugiej jest w swej historii solidarny z przyrodą (por. KKK 344).

s. 39-41. Świadectwa wiary w przemianę rzeczywistości ziemskiej wraz z przemianą człowieka można znaleźć również na kartach Nowego Testamentu. Zob. np.: „stworzenie z upragnieniem oczekuje objawienia się synów Bożych. Stworzenie bowiem zostało poddane marności (...) w nadziei, że również i ono zostanie wyzwolone z niewoli zepsucia, by uczestniczyć w wolności i chwale dzieci Bożych" (Rz 8, 19-21).

26 Por. J. GrzesicA, dz. cyt., s. 38-47, 71. Mówiąc na ten temat J. Grzesica cytuje: A. Auer, Lexikon für Theologie und Kirche. Das Zweite Vatikanische Konzil. Konstitutionen, Dekrete und Erklärungen, t. 3, Freiburg-Basel-Wien 1968, s. 52.

27 Por. J. SaliJ, dz. cyt., s. 120. 
Z naszkicowanej powyżej koncepcji wynika, że świat w ekoteologii jest projektem niedokończonym. Jako uczestnik dialogu z Bogiem, powinien niejako wyrazić siebie przez coraz większą doskonałość i zbliżenie do Boga. Taka możliwość zakłada oczywiście również alternatywę, którą jest odejście od Boga, co w praktyce przekłada się na zniszczenie świata. Bez tej alternatywy świat nie byłby jednak w ogóle zdolny do dialogu. Kluczową rolę w procesie budowania relacji z Bogiem ma do spełnienia człowiek, którego powołaniem jest «dokończenie» Bożego dzieła, udoskonalenie go w wymiarze moralnym. Stworzenie zakłada więc również działanie człowieka, jego twórczośćc ${ }^{28}$. To dzięki człowiekowi i jego działaniom rzeczywistość stworzona podejmuje dialog z Bogiem. Żyjąc w świecie i kształtując go, człowiek powinien także kształtować swoje podobieństwo do Boga. Działanie człowieka ma być dla świata błogosławieństwem ${ }^{29}$, choć trzeba przyznać, że może on przez swoją działalność albo wprowadzać pozytywne zmiany w środowisku, albo powodować jego degradację.

W świetle prowadzonych powyżej analiz interesujące wnioski można sformułować w kwestii ludzkiej podmiotowości. Okazuje się bowiem, że ową podmiotowość można rozważać nie tylko w relacjach człowiek-Bóg i człowiek-przyroda, ale także w relacji Bóg-stworzenie (rozumiane całościowo). W tej ostatniej relacji ludzką podmiotowość można odkrywać jako wyraz swoistej „podmiotowości świata".

\section{Autonomia świata jako etyczna granica ludzkiej podmiotowości}

Stwierdzenie, że moralność ludzkiego czynu jest związana z budowaniem za pomocą owego czynu relacji z Bogiem albo zrywania tej relacji w kontekście działań człowieka usytuowanych w rzeczywistości materialnej, jest dosyć enigmatyczne. W jaki sposób człowiek miałby rozpoznać, przez jakie czyny buduje relację, a przez jakie ją zrywa?

Przesłanka do udzielenia odpowiedzi na powyższe pytanie znajduje się w opowiadaniu o grzechu człowieka i jego konsekwencjach. Wypowiadane przez niewiastę słowa: „o owocach z drzewa, które jest w środku ogrodu, Bóg powiedział: Nie wolno wam jeść z niego, a nawet go dotykać" (Rdz 3, 3), kryją w sobie informację, że w przyrodzie istnieją prawa, których człowiek nie powinien łamać. Granica, o której mowa, jest oczywiście możliwa do przekroczenia - ma ona bowiem charakter etyczny a nie ontyczny. Ustanawiając granicę ontyczną Bóg zamknąłby możliwość dialogu ze sobą. Z perspektywy analizowanego przez nas tematu istotne jest, że człowiek powinien uszanować autonomię przyrody, między innymi wpisaną w nią celowość. Jego działania stają się moralnie dobre tylko wówczas, gdy szanują

\footnotetext{
28 Por. K. Töpfer, Ekologia i polityka, „Communio” 6 (1992), s. 80.
}

29 Por. W. KNOCH, dz. cyt., s. 5-6. 
owe prawa i wprowadzają w świat przyrody coraz większą harmonię ${ }^{30}$.

Przytoczona na początku analiz wypowiedź Soboru Watykańskiego II na temat autonomii świata rozwijana jest właśnie poprzez stwierdzenie o konieczności uwzględnienia w odniesieniach do przyrody tej relacji, jaka istnieje między Bogiem i stworzeniem: „Jeżeli jednak przez słowa «autonomia rzeczy doczesnych» rozumie się to, że rzeczy stworzone nie należą do Boga i że człowiek może z nich korzystać bez odniesienia do Stwórcy, każdy, kto uznaje Boga, czuje, jak fałszywe są to stwierdzenia. Stworzenie bowiem bez Stwórcy ginie" (KDK 36). Niniejsza myśl powtarzana jest również w innym fragmencie konstytucji duszpasterskiej, w którym podkreśla się prawomocność tylko działań sprawiających, że ziemia staje się odblaskiem chwały Boga: „Człowiek bowiem, stworzony na obraz Boga, otrzymał polecenie, aby poddając sobie ziemię we wszystkim, co się na niej znajduje, panował nad światem w sprawiedliwości i świętości oraz by uznając Boga za Stwórcę wszechrzeczy, odnosił do Niego siebie samego i całą rzeczywistość, tak aby mimo podporządkowania człowiekowi wszystkich rzeczy, imię Boże było wysławiane po całej ziemi” (KDK 34).

Prawda, że natura bytów, tworzących rzeczywistość przyrodniczą, jest kryterium moralności, została w sposób wyraźny sformułowana w encyklice Jana Pawła II Sollicitudo rei socialis. Papież nauczał w niej, że „moralny charakter rozwoju nie może (...) pomijać milczeniem poszanowania «bytów tworzących» widzialną naturę, którą Grecy, czyniąc aluzję właśnie do «porządku», jaki ją wyróżnia, nazwali «kosmosem»". Argumentując swoje stanowisko na pierwszym miejscu wskazał "«naturę każdego bytu» oraz ich "wzajemne powiązanie» w uporządkowany system, którym jest (...) kosmos" (nr 34). Dopiero na drugim i trzecim miejscu wymienił przesłanki typowo antropocentryczne, czyli konieczność zachowania zasobów naturalnych dla przyszłych pokoleń oraz potrzebę poprawy jakości życia ludności, szczególnie w rejonach mocno uprzemysłowionych (por. SRS 34). W konkluzji Jan Paweł II jeszcze raz podkreśla: „w odniesieniu do widzialnej natury jesteśmy poddani prawom nie tylko biologicznym, ale także moralnym, których nie można bezkarnie przekraczać" (SRS 34, por. KKK 2415). Człowiek nie powinien zatem uważać siebie za absolutnego władcę, który w sposób dowolny dysponuje rzeczami ${ }^{31}$. Jeszcze mocniejsze słowa padają w encyklice Centesimus annus: „Człowiek mniema, że samowolnie może rozporządzać ziemią, podporządkowując ją bezwzględnie własnej woli, tak jakby nie miała ona własnego kształtu i wcześniejszego, wyznaczonego jej przez Boga przeznaczenia, które człowiek, owszem, może rozwijać, lecz któremu nie może się sprzeniewie-

\footnotetext{
30 Por. J. Łukomski, Solidarność, s. 33.

31 Niniejsze myśli Jan Paweł II powtarza następnie w adhortacji apostolskiej Christifideles laici o powołaniu i misji świeckich w Kościele i w świecie. Zob. nr 43. Adhortacja zawarta w: Adhortacje apostolskie Ojca Świętego Jana Pawła II, Kraków 1997, s. 345-480.
} 
rzać" (nr 37) 32 . W swojej pierwszej encyklice Redemptor hominis Jan Paweł II użył porównania, które wskazuje na charakter ludzkiego «panowania». Człowiek ma być «stróżem», a nie bezwzględnym «eksploatatorem» (por. nr 15) ${ }^{33}$.

Benedykt XVI kontynuuje w tej kwestii nauczanie Jana Pawła II. W encyklice Caritas in veritate, mówiąc o relacji do przyrody, stwierdza: „Człowiekowi wolno sprawować odpowiedzialną władzę nad naturą, by jej strzec...” (CV 50) ${ }^{34}$. Owa odpowiedzialność powinna wyrażać się na przykład tym, że korzystając z przyrody, aby zaspokoić swe uprawnione potrzeby - materialne i niematerialne, człowiek dba o poszanowanie „wewnętrznej równowagi samego stworzenia” (CV 48).

Jak wynika z powyższych analiz, podmiotowość człowieka jest w ekoteologii wyraźnie powiązana z autonomią świata. Człowiek może, oczywiście, działać wbrew prawom, wpisanym w naturę stworzenia, którego powołaniem jest coraz większe upodabnianie się do Stwórcy poprzez wewnętrzną harmonię, ale wywołuje tym samym określone konsekwencje zarówno w swojej relacji z Bogiem, jak również w tej relacji, którą tworzy stworzenie jako całość ze Stwórcą. Jest to istotna przesłanka do sformułowania odpowiedzi na ostatnie, postawione we wstępie pytanie, które dotyczy propozycji w zakresie formowania odniesień człowieka do przyrody, prowadzących ją do coraz większej doskonałości i dających nadzieję na przezwyciężenie kryzysu ekologicznego.

\section{Integralny rozwój człowieka jako warunek realizacji wpisanych w przyrodę praw}

O ile panuje zgoda co do istnienia kryzysu ekologicznego, to - jak można zauważyć, analizując tezy ekoteologii i porównując je z postulatami kierunków antropocentrycznych i biocentrycznych - nie ma zgody co do tego, jakie są jego przejawy, jaki zakres i wreszcie, jakie sposoby przezwyciężenia. Odpowiedź na sformułowane tutaj pytania wymaga bowiem na przykład określenia, czy współczesna aktywność człowieka przyczynia się do rozwoju jego samego oraz rzeczywistości ziemskiej, czy wręcz przeciwnie, degraduje człowieka i świat. W poszczególnych wypowiedziach można z pewnością odnaleźć wiele stanowisk skrajnych, oceniających albo tylko optymistycznie zachodzące obecnie zmiany, albo poddających je radykalnej krytyce. Pierwsze włączają w kategorię rozwoju te działania, które uwarunkowane są jedynie hedonizmem, drugie kwestionują

32 Jan Pawe£ II, Encyklika Centesimus annus (odtąd CA z numerem artykułu), w: Encykliki Ojca Świętego Jana Pawła II, t. II, Kraków 1996. Por. W. BoŁoz, Integralna ochrona środowiska w nauczaniu Jana Pawła II, „Studia Ecologiae et Bioethicae” 6 (2008), s. 117-127; K. Wojciechowski, dz. cyt., s. 49.

33 Por. J. Synowiec, Na początku. Pradzieje biblijne: Rdz 1,1-11,9, Kraków 1996, s. 74.

34 Benedy Kt XVI, Encyklika o integralnym rozwoju ludzkim w miłości i prawdzie Caritas in veritate (odtąd CV z numerem artykułu), „L'Osservatore Romano” 30 (2009), nr 9 (316), s. 4-35. 
wartość tych osiągnięć, które autentycznie przyczyniają się nie tylko do dobra człowieka, ale także całej ziemskiej rzeczywistości.

Poszukując stanowiska ekoteologii w niniejszej kwestii, warto odwołać się do wypowiedzi Benedykta XVI, który, dostrzegając wagę problemów ekologicznych, uczynił je ważnym tematem swojego nauczania ${ }^{35}$. Nie ocenia on wprawdzie konkretnych ludzkich inicjatyw - ale na fundamencie przesłanek sformułowanych w ramach ekoteologii wskazuje na kryteria autentycznego rozwoju świata i człowieka.

W odniesieniach do samej przyrody Benedykt XVI wskazuje dwie skrajności. Pierwszą jest technicyzacja natury, traktowanie jej jako materii, którą można dysponować według własnych zachcianek, co prowadzi do nadużyć środowiska i przemocy względem niego. Druga skrajność polega na uważaniu natury za «nietykalne tabu» (por. CV 48) ${ }^{36}$. Skutkiem zbudowanej na pierwszym stanowisku postawy są widoczne na powierzchni ziemi «rany» w postaci erozji, wyciętych lasów, roztrwonionych bogactw mineralnych ${ }^{37}$. Konsekwencją drugiego stanowiska jest panteizm i postawy neopogańskie (ŚDzP2010 13; CV 48).

Implikacją powyższych stanowisk są różne koncepcje rozwoju człowieka. W wyniku przyjęcia pierwszego stanowiska pojawia się «nadrozwój» w wymiarze technicznym, któremu towarzyszy «niedorozwój moralny» (CV 29). Człowiek

35 Refleksji na temat ochrony środowiska Benedykt XVI poświęcił uwagę w encyklice Caritas in veritate. Ochrona środowiska stała się przedmiotem rozważań również w innych dokumentach i wypowiedziach, przykładowo: Osoba ludzka sercem pokoju (Orędzie na XL Światowy Dzień Pokoju 1 stycznia 2007 - odtąd ŚDzP2007), „L'Osservatore Romano” 28 (2007), nr 2 (290), s. 4-9; Rodzina wspólnotą pokoju (Orędzie na XLI Światowy Dzień Pokoju 1 stycznia 2008), „L'Osservatore Romano" 29 (2008), nr 1 (299), s. 25-28; Zwalczanie ubóstwa droga do pokoju (Orędzie na XLII Światowy Dzień Pokoju 1 stycznia 2009), „L'Osservatore Romano” 30 (2009), nr 1(309), s. 3-9; Jeśli chcesz krzewić pokój, strzeż dzieła stworzenia (Orędzie na XLIII Światowy Dzień Pokoju 1 stycznia 2010 roku - odtąd ŚDzP2010), „L'Osservatore Romano” 31 (2010), nr 1 (319), s. 4-8; Droga pokory nie jest droga rezygnacji, lecz odwagi (homilia podczas pielgrzymki do Loreto, 2.IX.2007), „L'Osservatore Romano” 28 (2007), nr 10-11 (297), s. 9-11; Boże Narodzenie świętem odrodzonego stworzenia (homilia podczas Pasterki w Bazylice św. Piotra, 24.XII.2007), „L'Osservatore Romano" 29 (2008), nr 2 (300), s. 17-18; Niech Duch Święty odnowi ten kraj (przemówienie podczas ceremonii powitania na XXIII Światowych Dniach Młodzieży, 17.VII.2008), „L'Osservatore Romano" 29 (2008), nr 9 (306), s. 11-12; Ochrona środowiska jest ściśle związana z integralnym rozwojem człowieka (audiencja generalna, 26.VIII.2009), „L'Osservatore Romano” 30 (2009), nr 10 (317), s. 34-35; Musimy jak najszybciej zwalczyć głód i niedożywienie na świecie (przemówienie w FAO na rozpoczęcie spotkania poświęconego bezpieczeństwu żywnościowemu, 16.XI.2009), „L'Osservatore Romano” 31 (2010), nr 1 (319), s. 22-24; Miłość bliźniego i sprawiedliwość w stosunkach międzynarodowych i międzypaństwowych (przesłanie z okazji XIII Sesji Plenarnej Papieskiej Akademii Nauk Społecznych), „L'Osservatore Romano” 28 (2007), nr 7-8 (295), s. 5-7.

36 Zob. na temat tego problemu również: J. GrzesicA, dz. cyt., s. 38-47.

37 Por. Benedykt XVI, Niech Duch Święty, s. 11-12; por. także tenże, Boże Narodzenie świętem, s. 18. 
wyłącznie «technologiczny» nie jest z kolei zdolny, zdaniem Papieża, do wyznaczania swoim działaniom obiektywnych celów i odpowiedniego posługiwania się narzędziami, które ma do dyspozycji (por. CV 21). Jan Paweł II w mocnych słowach ocenił taką postawę: „Widać w tym raczej ubóstwo czy raczej miernotę sposobu patrzenia człowieka, kierowanego żądzą posiadania rzeczy bardziej niż chęcią odnoszenia ich do prawdy, nie posiadającego owej postawy bezinteresownej, szlachetnej, wrażliwej na wartości estetyczne" (CA 37).

Drugie stanowisko prowadzi do generalnego zanegowania rozwoju, który uważany jest za nieludzki i prowadzący jedynie do degradacji człowieka i środowiska. Tymczasem w dokumentach kościelnych XX wieku ogólnie pozytywnie odnoszono się do efektów ludzkiej aktywności w świecie ${ }^{38}$. Podobne stanowisko zajął Benedykt XVI. Na Światowych Dniach Młodzieży w Sydney podkreślił: „Każdego dnia doświadczamy geniuszu ludzkich osiągnięć. Poprzez postęp w naukach medycznych i mądre zastosowanie technologii aż po kreatywność odzwierciedloną w sztuce, jakość i radość życia stopniowo wzrasta"39. Z kolei $\mathrm{w}$ encyklice Caritas in veritate wyraźnie potępił te głosy, które jednoznacznie negatywnie oceniały wszelkie dzieła człowieka: „W ten sposób dochodzi się do potępienia nie tylko błędnego i niesprawiedliwego sposobu, w jaki ludzie niekiedy nadają kierunek rozwojowi, ale też samych odkryć naukowych, które - jeśli dobrze wykorzystane - stwarzają sposobność wzrostu dla wszystkich" (CV 14).

Benedykt XVI postuluje zatem troskę o rozwój, który będzie miał charakter integralny, czyli taki, którego istotnym wymiarem jest dojrzewanie moralne. Taki profil rozważań nad rozwojem człowieka w sferze odniesień do przyrody został zasugerowany przez Papieża już w orędziu na Światowy Dzień Pokoju w 2007 roku: „Niszczenie środowiska, korzystanie z niego w sposób niewłaściwy lub egoistyczny i zagarnianie przemocą dóbr naturalnych ziemi rodzą rozdarcia, konflikty i wojny, właśnie dlatego, że są owocem nieludzkiego pojmowania rozwoju. Rozwój bowiem, który ograniczałby się tylko do aspektu techniczno-ekonomicznego, z pominięciem wymiaru moralno-religijnego, nie byłby ludzkim rozwojem integralnym i, jako jednostronny, prowadziłby do rozkwitu niszczących możliwości człowieka" (ŚDzP2007 9). Postęp techniczny powinien być zatem połączony z rozwojem w zakresie miłości, odpowiedzialności czy solidarności (por. CV 11, 19).

Ponieważ indywidualna moralność potrzebuje sprzyjających warunków do rozwoju, dlatego w Caritas in veritate Papież apeluje, aby tworzyć takie uwarunkowania społeczno-ekonomiczne, które będą umożliwiały działania bezinteresowne. Stwierdza na przykład: „Ekonomia zglobalizowana (...) potrzebuje również (...) logiki daru bez rekompensaty" (CV 37). Podobny apel skierowany jest do współczesnych społeczeństw: „Stanowi to wezwanie dla dzisiejszego społe-

\footnotetext{
38 Por. P. KęDzierski, dz. cyt., s. 10-12; T. ŚlipKo, dz. cyt., s. 81-82.
}

39 Benedykt XVI, Niech Duch Święty, s. 11-12. 
czeństwa, by poważnie zrewidowało swój styl życia, który w wielu częściach świata skłania się do hedonizmu i konsumpcjonizmu, pozostając obojętnym na wynikające z tego szkody. Potrzebna jest skuteczna zmiana mentalności, która nas skłoni do przyjęcia nowych stylów życia, «w których szukanie prawdy, piękna i dobra, oraz wspólnota ludzi dążących do wspólnego rozwoju byłyby elementami decydującymi o wyborze jakości konsumpcji, oszczędności i inwestycji»” (CV 51).

Mówiąc o rozwoju integralnym w ekoteologii, nie można zapomnieć, że realizuje się on w kontekście rozwoju relacji z Bogiem. Przyjmując sposób oceny i wartościowania świata, zaprezentowany w pierwszej części artykułu, nie sposób nie dostrzec, że współczesne myślenie o świecie alienuje go z relacji do Boga. Nie tylko człowiek zrywa tę relację, ale również sam świat traktuje jakby istniał poza relacją do Boga ${ }^{40}$. Fundamentalnym problemem dla współczesnego myślenia o świecie jest zatem postrzeganie go jedynie w wymiarze horyzontalnym osadzanie w dwuelementowym schemacie, ale innym niż omawiany powyżej, ponieważ złożonym wyłącznie ze świata i człowieka ${ }^{41}$. Jacek Salij łączy ten fakt z kryzysem ekologicznym, mówiąc, że dopiero w Europie zdechrystianizowanej pojawiła się maniera instrumentalnego traktowania przyrody $y^{42}$. Inną konsekwencją wertykalnego myślenia o świecie jest odebranie przyrodzie jej autonomii. Wskazując na tę zależność, ekoteologia łączy szanse na przezwyciężenie kryzysu ekologicznego z odnową relacji między człowiekiem i Bogiem, oraz z dostrzeżeniem przez człowieka, że jego relacja z przyrodą ma także wymiar wertykalny ${ }^{43}$. Można więc powiedzieć, że efektem odkrycia własnej relacji z Bogiem powinno być uznanie, że świat «nie jest moją własnością» - czyli moje działania powinny uwzględniać prawa rządzące przyrodą i jej relację ze Stwórcą, w ramach której konstytuowana jest celowość rzeczywistości materialnej. Wypowiedzi Benedykta XVI zwracają uwagę na ten problem. W encyklice Caritas in veritate znajdują się słowa: „Bez perspektywy życia wiecznego postęp ludzki na tym świecie pozbawiony jest oddechu. Zamknięty w ramach historii wystawiony jest na ryzyko, że będzie sprowadzony jedynie do tego, by coraz więcej mieć" (nr 11).

40 Por. C. Naumowicz, Eko-teologia jako forma chrześcijańskiej diakonii wobec stworzenia, „Studia Ecologiae et Bioethicae" 7 (2009), nr 1, s. 224.

41 Por. T. Ślipko, dz. cyt., 102-107; P. KęDZIERSKI, dz. cyt., s. 20-25.

42 Por. J. SAliJ, dz. cyt., s. 101, 161. Owo przyzwolenie na instrumentalne traktowanie przyrody przekłada się na praktykę podejścia do przyrody. Jacek Salij zauważa, że nawet wśród ludności wiejskiej ginie dzisiaj poczucie zbratania z przyrodą i coraz bardziej zwycięża nastawienie czysto produkcyjne. W wielkich tuczarniach czy fermach zwierzęta dzisiaj nie są hodowane ale „produkowane". Por. tamże, s. 187-188.

43 Por. S. Urbański, dz. cyt., s. 317-327; T. Brzegowy, Pięcioksiag Mojżesza. Wprowadzenie i egzegeza Księgo Rodzaju 1-11,Tarnów 1997, s. 146-147; J. Łukomsкi, Solidarność, s. 34. 


\title{
Zakończenie
}

Zadaniem kultury przełomu XX i XXI wieku jest zmierzenie się z kryzysem ekologicznym. Nie jest to problem jedynie techniczny, ponieważ u jego fundamentów znajduje się mentalność współczesnego człowieka, nastawionego na konsumpcję i w związku z tym instrumentalnie podchodzącego do świata materialnego. Wśród wielu propozycji ułożenia na nowo relacji między człowiekiem i przyrodą znajduje się również koncepcja chrześcijańska, wskazująca na konieczność poszerzenia rozważań nad ową relacją o wymiar wertykalny. W kontekście relacji wertykalnej, relacji z Bogiem, przyroda jawi się jako rzeczywistość celowa i autonomiczna, a nie jako przypadkowo ukształtowana masa, którą można dowolnie przekształcać. Równocześnie w koncepcji tej nie jest deprecjonowana podmiotowość człowieka, choć dla niej autonomia przyrody staje się ograniczeniem o charakterze moralnym. Ponadto, w ramach tej koncepcji, możliwe jest spojrzenie na świat, włączające go w szeroką definicję człowieka.

\section{The autonomy of the world and the subjectivity of man in ecotheology}

\author{
SUMMARY
}

One of the most difficult problems, which is to be solved by contemporary culture, is the ecological problem. It concerns the culture, because the hedonistic and consumerist mentality of man plays an important part in it. Biocentrism states that the ecological problem results from traditional Western attitudes to the non-human world based on the belief that humans are the central and most significant entities in the universe. Biocentrism puts forward a teleological argument for the protection of the environment. It indicates that non-human species have inherent value as well and each organism has a purpose and a reason for being, which should be respected. Biocentrism states that the anthropocentric attitude to the non-human world results from the Christian worldview based on the Bible where it is written that God gives man dominion over all creatures. The author analyses the main issues of the Catholic concept of relationship between the human being and other creatures. He indicates that ecothology respects the inherent value of non-human creatures because, as the Pastoral constitution on the Church in the modern world Gaudium et spes says: "all things are endowed with their own stability, truth, goodness, proper laws and order", but maintains that the purpose of the world is connected with its relationship to God. The author considers also what is the human subjectivity in behaving towards the environment and what is the dependence between the autonomy of the world and the subjectivity of man in ecotheology. In the end the author comes to the conclusion that according to ecotheology the ecological problem results from the broken relationship between the human and God and in consequence of it the broken relationship between the world and God. 